\title{
On the influence of sea level and monsoon climate on the southern South China Sea freshwater budget over the last 22,000 years
}

\author{
Stephan Steinke ${ }^{\mathrm{a}, *, 1}$, Han-Yi Chiu ${ }^{\mathrm{b}}$, Pai-Sen $\mathrm{Yu}^{\mathrm{c}}$, Chuan-Chou Shen ${ }^{\mathrm{b}}$, Helmut Erlenkeuser ${ }^{\mathrm{d}}$, \\ Ludvig Löwemark ${ }^{\mathrm{b}}$, Min-Te Chen ${ }^{\mathrm{c}}$ \\ ${ }^{a}$ DFG Forschungszentrum Ozeanränder-Research Center Ocean Margins (RCOM), Universität Bremen, Postfach 3304 40, D-28334 Bremen, Germany \\ ${ }^{\mathrm{b}}$ Department of Geosciences, National Taiwan University, Taipei, Taiwan \\ ${ }^{\mathrm{c}}$ Institute of Applied Geosciences, National Taiwan Ocean University, Keelung, Taiwan \\ ${ }^{\mathrm{d}}$ Leibniz-Labor für Altersbestimmung und Isotopenforschung, Universität Kiel, Kiel, Germany
}

Received 1 March 2005; accepted 15 December 2005

\begin{abstract}
Changes in the local freshwater budget over the last 22,000 years have been estimated from a sediment core located in the southern South China Sea (SCS) using a combined approach of $\mathrm{Mg} / \mathrm{Ca}$ and oxygen isotopes on the planktonic foraminifera Globigerinoides ruber (white) sensu stricto (s.s.). Core MD01-2390 $\left(06^{\circ} 28,12 \mathrm{~N}, 113^{\circ} 24,56 \mathrm{E}\right.$; water depth $\left.1591 \mathrm{~m}\right)$ is located near the glacial paleo-river mouths of the Baram, Rajang and North Sunda/Molengraaff Rivers that drained the exposed Sunda Shelf. The $\delta^{18} \mathrm{O}_{\text {seawater }}$ record reveals lower average values $(-0.96 \pm 0.18 \%$ ) during the Last Glacial Maximum (LGM) when compared with modern values $(-0.54 \pm 0.18 \%$ ). Low salinity during the LGM is interpreted to reflect a higher freshwater contribution due to a greater proximity of the core site to the mouths of the Baram, Rajang and North Sunda/Molengraaff Rivers at that time. A general deglacial increasing trend in salinity due to the progressive landward displacement of the coastline during deglacial shelf flooding is punctuated by several short-term shifts towards higher and lower salinity that are likely related to abrupt changes in the intensity of the East Asian summer monsoon. Thus, the deglacial $\delta^{18} \mathrm{O}_{\text {seawater }}$ changes reflect the combined effects of sea-level-induced environmental changes on the shelf (e.g. phases of retreat and breakdown of the shelf drainage systems) and East Asian monsoon climate change. Lower salinity than at present during the Early Holocene may be attributed to an increase in summer monsoonal precipitation that is corroborated by previous marine and terrestrial studies that report a Preboreal-Early Holocene monsoon optimum in the Asian monsoon region.
\end{abstract}

(C) 2006 Elsevier Ltd. All rights reserved.

\section{Introduction}

Variations in sea surface salinity (SSS) are strongly related to the balance between evaporation and precipitation and thus represent a sensitive tracer of climate variability (e.g. Rosteck et al., 1993). Near the continental margins, salinity reconstructions may also provide important information about the variability of the riverine input as a result of changes in continental humidity/aridity, and/ or the variable proximity of river mouths to core locations in response to changes in sea level (Wang et al., 1995). In

\footnotetext{
*Corresponding author. Tel.: + 4942121865882 ; fax: + 4942121865515 .

E-mail address: ssteinke@uni-bremen.de (S. Steinke).

${ }^{1}$ Previously at Institute of Applied Geosciences, National Taiwan Ocean University, Keelung, Taiwan.
}

the case of the southern South China Sea (SCS), on the western edge of the Western Pacific Warm Pool (WPWP), however, previous salinity reconstructions display a controversial picture concerning the salinity structure of the southern SCS during the last glacial period. Based on recent high-resolution alkenone, $\mathrm{Mg} / \mathrm{Ca}$ and oxygen isotope time series of the SCS (core 17961, Pelejero et al., 1999a; cores 18252 and 18287, Kienast et al., 2001) and the Sulu Sea (MD97-2141; Rosenthal et al., 2003), Kuhnt et al. (2004) calculated lower average glacial $\delta^{18} \mathrm{O}_{\text {seawater values }}$ in the central SCS (core 17961), off the paleo-Mekong River (core 18252) and the Sulu Sea (MD97-2141; see Figs. 1 and 2 for site locations), suggesting a regional decrease in surface water salinity during the Last Glacial Maximum (LGM). Lower glacial salinity has been partly attributed to changes in the basin geometry when the 


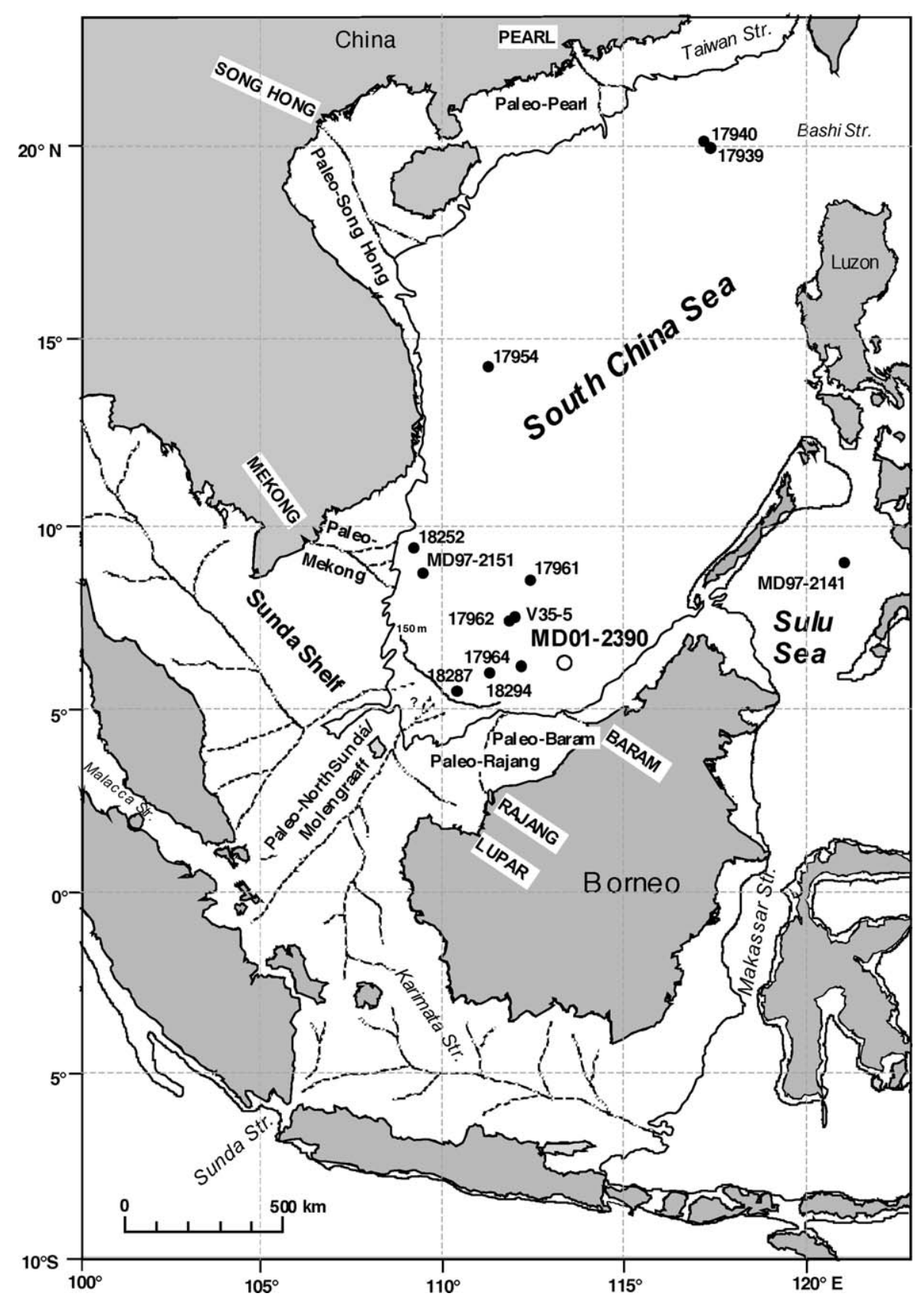

Fig. 1. Map of the South China Sea showing the location of core MD01-2390. The locations of other cores discussed in the text are also indicated (solid dots): 17939, 17940, 17954, 17961 and 17964 (Wang et al, 1999; Pelejero et al., 1999a,b, Wang, 2000); 17962 (Hu et al., 2003 ); 18252 and 18287 (Kienast et al., 2001; Steinke et al., 2001); V35-5 (Duplessy et al., 1991); MD97-2151 (Huang et al., 2002; Chen et al., 2005); and MD97-2141 (Oppo et al., 2003; Rosenthal et al., 2003). The 100-m isobath (thick dark line) approximately represents the coastline during the last glacial maximum. Stippled lines indicate the assumed courses of the major paleo-rivers on the (emerged) glacial Sunda Shelf as adapted from Molengraaff (1921), Voris (2000) and Hiscott (2001).

southern straits (e.g. Karimata, Sunda and Malacca Straits) were closed during glacial shelf exposure, cutting off the inflow of higher saline waters from the Indo-Pacific and thus enhancing glacial freshening of these marginal seas (Wang et al., 1999; Pelejero et al, 1999a; Oppo et al., 2003; Rosenthal et al., 2003). Furthermore, Oppo et al. (2003) suggested that increased rainfall due to a more southern shift of the Intertropical Convergence Zone (ITCZ) and/or decreased total evaporation due to a reduction of the sea area and cooler temperature conditions resulted in a glacial freshening in the SCS and Sulu
Sea Basins. However, it is still a controversial issue if the glacial freshening of the southern SCS and Sulu Sea was driven by an increased run-off from the southern land masses as a direct result of changes in continental humidity and/or sea level. A lateral shift of the river mouths towards the core sites could have led to lower salinities at these sites. In contrast, salinity reconstructions for the LGM off the paleo-North Sunda/Molengraaff River have revealed higher (core 17964; Pelejero et al., 1999a) and unchanged salinity structures (core 18287; based on calculations by Kuhnt et al., 2004) than during the Late Holocene. 

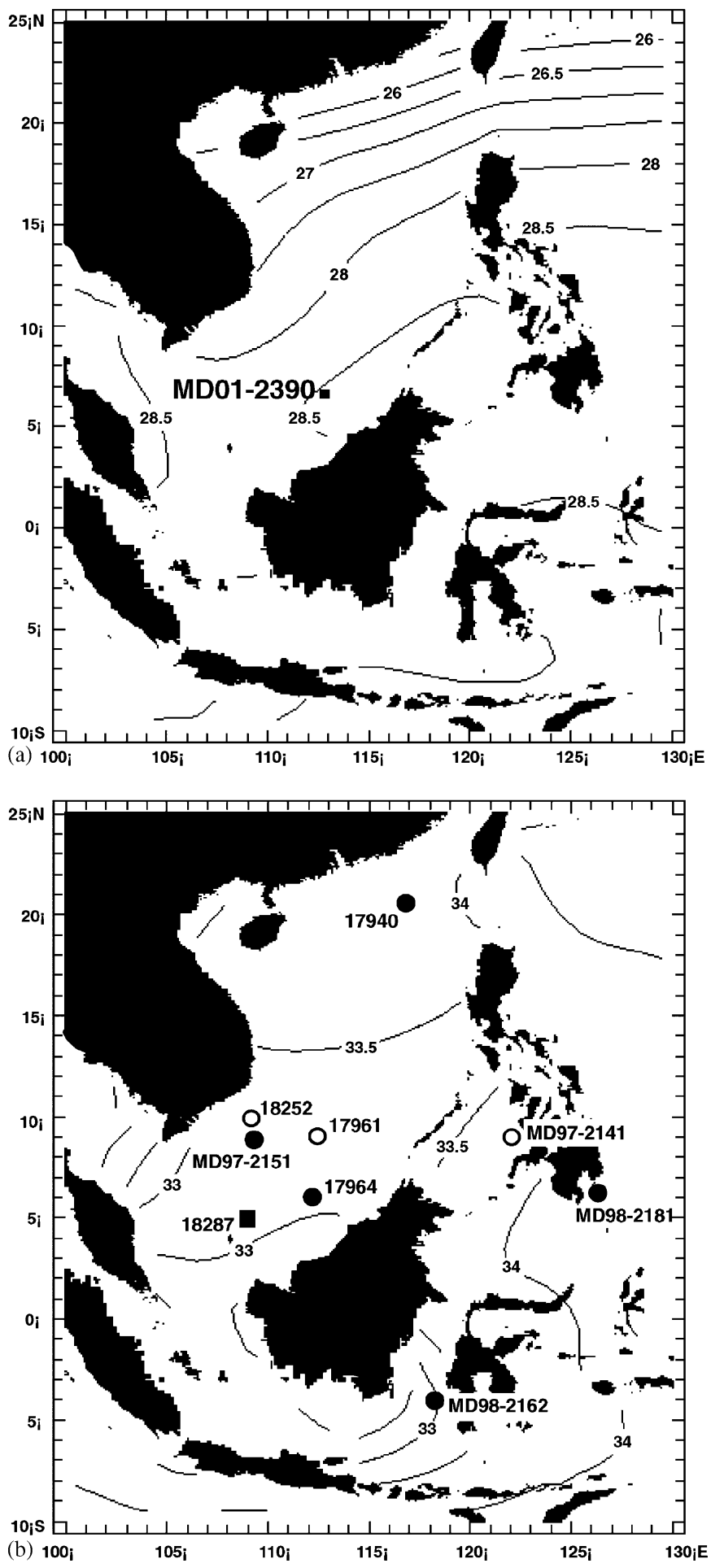

Fig. 2. Mean annual (a) SST and (b) SSS (Levitus and Boyer, 1994). Previous estimated changes in SSS during the LGM are shown in (b): 17940 (Wang et al., 1999), 17961 and 17964 (Pelejero et al., 1999a,b); 18252 and 18287 (Kuhnt et al., 2004, based on data of Kienast et al., 2001); MD97-2151 (Huang et al., 2003; Chen et al., 2005); MD97-2141 (Oppo et al., 2003; Rosenthal et al., 2003); MD98-2181 (Stott et al., 2002); and MD98-2162 (Kuhnt et al., 2004; based on data of Visser et al., 2003). Solid dots indicate higher and open dots lower salinities during the LGM compared to modern times. Black boxes indicate sites where there is no apparent change.
According to Pelejero et al. (1999a), this feature is counterintuitive since coring site 17964 is located close to the paleo-Molengraaff/North Sunda River that crossed the exposed Sunda Shelf during glacial times and should thus display lower salinities (see Fig. 1 for the core location and paleo-course of the Molengraaff or North Sunda River). Higher salinities at station 17964, however, could be due to local upwelling during this period (Pelejero et al., 1999a). Higher salinities during the last glacial in the southern SCS (core MD97-2151) are also suggested by studies of Huang et al. (2003) and Chen et al. (2005). Salinity reconstructions off Mindanao also yields saltier conditions during the last glacial compared with the present (Stott et al., 2002). This is interpreted to reflect a glacial shift in the tropical Pacific ocean/atmosphere system towards El Niño-like conditions. In contrast, Lea et al. (2000) argue in favour of more La Niña-like conditions since $\delta^{18} \mathrm{O}_{\text {seawater }}$ reconstructions from a core located on the Ontong Java Plateau reveal fresher conditions relative to the present in the western equatorial Pacific during the last glacial period.

Terrestrial, marine and modelling studies, however, reveal a controversial picture concerning the climatic state (drier vs. more humid) of the southeastern (SE) Asian region during the last glacial period. Palynological and organic geochemical studies of cores 17964 (Sun et al., 2000) and 17962 (Hu et al., 2003) off the Sunda Shelf reveal that tropical (lowland) rainforest occupied the glacial Sundaland, indicating characteristics of presentday humid conditions. Evidence based on lignin phenol ratios analysed in a core recovered in the Makassar Strait suggests that vegetation on Borneo and other surrounding islands did not significantly change from tropical rainforest during the last glacial period relative to the interglacial (Visser et al., 2004). In accordance with these interpretations, atmospheric model simulations indicate that presentday humid conditions in this region also prevailed during the LGM (Bush and Fairbanks, 2003). LGM simulations also reveal strong precipitation over Indonesia (Bush, 2004) and extensive wetland systems existed on the exposed Sunda Shelf (Kaplan, 2002). In contrast, generally drier conditions in SE Asia during the LGM are predicted by general circulation models by Prell and Kutzbach (1987). This is corroborated by paleo-ecological studies of Van Campo et al. (1993), Flenley (1998), van der Kaars et al. (2000) from the Banda Sea, Hope (2001) and Dam et al. (2001) for Sulawesi, van der Kaars et al. (2001) for WestJava, and Penny (2001) for NW Thailand. In contrast to these studies, Taylor et al. (2001) infer humid glacial conditions with potentially seasonal dry climates in Singapore during the last glacial.

Here, we use a combination of $\mathrm{Mg} / \mathrm{Ca}$ measurements and stable oxygen isotopes of the planktonic foraminifera Globigerinoides ruber (white) sensu stricto (s.s.) from the southernmost SCS at IMAGES site MD01-2390 in order to resolve the hydrographic history of the tropical SCS over the last $\sim 22,000$ years. The $\mathrm{Mg} / \mathrm{Ca}$ paleothermometer has the special advantage of being an independent temperature 
proxy that is measured on the same medium (foraminiferal calcite) as $\delta^{18} \mathrm{O}$ thereby allowing the temperature and seawater $\delta^{18} \mathrm{O}$ signal to be separated. Moreover, measuring the same species excludes interfering seasonality and/or habitat effects occurring when using proxy data from different faunal groups (Barker et al., 2005). By performing the different measurements on the same species in the same size fraction, the problems caused by bioturbation and abundance variations of the foraminifera, which may lead to serious shifts in the proxy signals between different species (e.g., Matisoff, 1982; Mangini and Schlosser, 1986; Trauth, 1998), could also be circumvented.

\section{Hydrographic setting-present and past}

The SCS, on the western edge of the WPWP, is a semienclosed marginal basin situated between the East Asian land mass and the western Pacific. It is connected to the Pacific Ocean via the Bashi Strait in the northeast and to the tropical Indo-Pacific via the Sunda Shelf in the south. At present, the flow direction of surface water masses and the hydrographic patterns of the SCS are largely controlled by drift currents due to the seasonally reversing East Asian monsoonal regime (Wyrtki, 1961; Shaw and Chao, 1994). During winter, high-pressure systems develop over Asia, causing cold and dry winds (northeasterly monsoon; October to March), whereas during summer, low-pressure systems develop over Asia, drawing in maritime tropical air masses and causing summer precipitation (southwesterly monsoon; May to September; Ding, 1994). During the winter monsoon season, the cold northeasterly winds together with the southward flow of the cold Chinese Coastal waters result in low sea surface temperatures (SSTs) in the northern SCS and a strong N-S temperature gradient within the SCS, while during the summer monsoon season, warm Indo-Pacific ocean surface waters flow into the southern SCS across the Sunda Shelf through the Karimata, Sunda and Malacca Straits (Wyrtki, 1961; Hellermann and Rosenstein, 1983). The summer SSTs are uniformly high $\left(28-29^{\circ} \mathrm{C}\right)$ throughout the SCS. Salinities in the SCS vary seasonally in response to the monsoonal rains and annual changes in circulation pattern causing an interchange of low- and high-salinity surface water masses (Wyrtki, 1961; Fig. 2). Lower SSS in the SCS during summer season (29-34 psu) reflect the generally higher precipitation, whereas during winter, the salinity (30-35 psu) reflects the decreased precipitation combined with the inflow of higher saline surface water masses through the northern straits, the Bashi and Taiwan Straits. Values below 33 psu are recorded near river deltas (e.g. off the Mekong Delta throughout the year). Salinity near the mouth of the large rivers off Borneo is reduced to $30 \mathrm{psu}$ at the end of the rainy season (Wyrtki, 1961).

During the LGM, sea-level lowering caused significant modifications in the land-sea configuration of the SCS. The SCS lost half its area as a result of shelf exposure, which changed its configuration into a semi-enclosed 'sack-like' basin (Wang, 1999). The straits that connect the SCS in the south were closed allowing no exchange of warm-saline waters between the SCS and the Indo-Pacific. During this time, the Bashi Strait, located between Taiwan and the Philippines, with a sill depth of $2500 \mathrm{~m}$, was the only open connection to the western Pacific. Besides sea-level-induced changes in the hydrography and oceanography, the SCS paleoceanography was also sensitive to changes in the monsoon system. Several studies based on terrestrial and marine records showed enhanced winter monsoon during the LGM (An et al., 1991; Wang et al., 1999; An, 2000). This led to an inflow of cold surface water from the northeast via the Bashi Strait causing a marked decrease in winter SST and a deepening of the mixed layer, as proposed by Wang and Wang (1990), Wang et al. (1995), Wang et al. (1999) and Huang et al. (1997a, b). Sea-level lowering must also have had a significant influence on the salinity of the SCS. Several rivers, such as the Molengraaff or North Sunda River and the paleo-Mekong River crossed the exposed shelf areas and entered the SCS much closer to the central parts of the basin. During the deglacial sea-level rise, the flooding of the Sunda Shelf consequently led to a breakdown of the glacial drainage systems. The southern straits connecting the SCS with the tropical Indo-Pacific (e.g. Karimata, Malacca and Sunda Straits; Fig. 1) were reopened, allowing the establishment of modern surface water circulation with an inflow of higher salinity waters to the SCS basin (Wang and Wang, 1990; Wang et al., 1995; Wang, 1999; Wang et al., 1999; Pelejero et al., 1999a, b).

\section{Materials and methods}

\subsection{Core MD01-2390}

CALYPSO gravity core MD01-2390 (06 $38,12 \mathrm{~N}$; $113^{\circ} 24,56 \mathrm{E}$; water depth of $1545 \mathrm{~m}$ ) was recovered during R/V Marion Dufresne 122/IMAGES VII-WEPAMA (Leg 1) cruise in 2001 on the Nansha Shallow of the southern SCS (Holbourn et al., 2002; see Fig. 1 for core location). Core MD01-2390 is located in the vicinity of the Baram, Rajang and the former North Sunda/Molengraaff Rivers (Fig. 1). The core site was only ca $50 \mathrm{~km}$ away from the paleo-Baram River mouth during the LGM, when sea level dropped by $\sim 120 \mathrm{~m}$ (e.g. Hanebuth et al., 2000). Shallow seismic profiles and sedimentological descriptions of the analysed upper $900 \mathrm{~cm}$ (total length of core MD01-2390 is $43.73 \mathrm{~m}$ ) of the core revealed undisturbed light olive to olive grey nannofossil and foraminifera-bearing clay. Organic rich spots occur in the depth interval of $300-900 \mathrm{~cm}$ (10,000-22,000 cal-yr BP), indicating a high supply of organic terrestrial matter when the core site was close to the glacial coastline (Steinke et al., 2003).

\subsection{Oxygen isotope analyses and ${ }^{14} \mathrm{C}$ dating}

Core MD01-2390 was sampled at regular 5-cm intervals $(12.5-502.5 \mathrm{~cm})$ and $10-\mathrm{cm}$ intervals $(512.5-900 \mathrm{~cm})$ for 
oxygen isotope analyses on the near-surface-dwelling planktonic foraminifera $G$. ruber (white) s.s. Oxygen isotope ratios were determined on samples composed of $15-20$ specimens in the $250-350 \mu \mathrm{m}$ size fraction. The number of specimens and the rather narrow size fraction were chosen to minimize the influence of vital effects (Berger et al., 1978) and to average out the signal noise linked to seasonal variations. Prior to the measurements, all foraminiferal tests were manually crushed, washed in ethanol $(99.8 \%)$ in an ultrasonic bath and dried at $40{ }^{\circ} \mathrm{C}$. The measurements were performed at the Leibniz Laboratory (University of Kiel) with the Carbo-Kiel automated preparation system (Kiel I type device) coupled to a Finnigan MAT 251 mass spectrometer. The external error of the stable oxygen isotope analyses is $\pm 0.08 \%$ PDB. Accelerator mass spectrometry (AMS) ${ }^{14} \mathrm{C}$-datings were performed on monospecific samples of planktonic foraminifera G. ruber (white) or G. sacculifer. Due to the lack of sufficient specimens for monospecific foraminifera samples, one dating $(557.5 \mathrm{~cm})$ was obtained on a mixed sample of G. ruber and G. sacculifer (see Table 1). Radiocarbon age determinations were performed at the Tandetron AMS facility at the Nagoya University Center for Chronological Research, Japan. Conventional radiocarbon ages were corrected for isotopic fractionation using $\delta^{13} \mathrm{C}$ values. All radiocarbon ages were calibrated using version 4.3 of the CALIB radiocarbon software (Stuiver et al., 1998) using the marine calibration data set INTCAL98 (0-24,000 cal-yr BP; Stuiver et al., 1998) without a further adjustment for a regional ${ }^{14} \mathrm{C}$ reservoir age $(\Delta R=$ deviation from the average global reservoir age of 400 years). Between age control points, ages have been linearly interpolated using the program AnalySeries 1.1. (Paillard et al. 1996), assuming constant sedimentation rates. In the following text, all ages refer to calibrated (cal) years BP.

\section{3. $\mathrm{Mg} / \mathrm{Ca}-\mathrm{SST}$ estimates}

$\mathrm{Mg} / \mathrm{Ca}$ analyses on $G$. ruber s.s. were run on a subset of samples with $5-10 \mathrm{~cm}$ spacing. For each sample, approxi- mately 30-40 specimens $(330-420 \mu \mathrm{g})$ of G. ruber (white) s.s. were picked out of the $250-350 \mu \mathrm{m}$ fraction. Samples that did not contain enough specimens complying with the s.s. morphotype requirements (Wang, 2000) were supplemented with as many sensu lato (s.l.) tests as necessary to reach the amount of tests required for reliable measurements. Foraminiferal tests were cleaned in successive steps following the cleaning protocol developed by Barker et al. (2003) and analysed on a Q-ICPMS (Agilent 7500s), housed at the Department of Geosciences, National Taiwan University. The accuracy of Q-ICPMS techniques was calibrated with primary standard solutions, which were prepared gravimetrically with ultrapure chemicals (Shen et al., 2004). The precision and external uncertainty are $0.1-0.2 \%$ and $0.4 \%$, respectively (Shen et al., 2004). $\mathrm{Mg} / \mathrm{Ca}$ ratios were converted to SST by means of the species-specific calibration for $G$. ruber (white; size fraction 250-350 $\mu \mathrm{m}$; Hastings et al., 2001) from the SCS surface sediment samples recovered from water depths less than $2000 \mathrm{~m}: \mathrm{Mg} / \mathrm{Ca}(\mathrm{mmol} / \mathrm{mol})=0.38 \exp \left[0.089 \mathrm{SST}\left({ }^{\circ} \mathrm{C}\right)\right]$. The standard error of estimates for various temperature equations derived from core-top and trap calibrations is typically in the range of $0.5-1.0{ }^{\circ} \mathrm{C}$ (Elderfield and Ganssen, 2000; Lea et al., 2000; Hastings et al., 2001; Dekens et al., 2002; Anand et al., 2003).

\section{4. $\delta^{18} O_{\text {seawater }}$ estimates}

$\delta^{18} \mathrm{O}_{\text {seawater }}$ was calculated by removing the temperaturedriven component of changes in the $\delta^{18} \mathrm{O}_{\text {G.ruber }}$ record using the temperature- $\delta^{18} \mathrm{O}_{\text {seawater }}$ relationship $\left(\delta^{18} \mathrm{O}_{\text {seawater }}\right.$ $\left.=\left(T-16.5+4.8 \times \delta^{18} \mathrm{O}_{\text {calcite }}\right) / 4.8+0.27\right)$ given by Bemis et al. (1998). According to Lea et al. (2000), the estimated uncertainty of the $\delta^{18} \mathrm{O}_{\text {seawater }}$ data is $0.18 \%$, calculated from the uncertainty in the paleotemperature equation, the standard error of the $\mathrm{Mg} / \mathrm{Ca}-\mathrm{SST}$ calibration and the reproducibility of $\delta^{18} \mathrm{O}_{\text {calcite }}$ and $\mathrm{Mg} / \mathrm{Ca}$ measurements. The component of $\delta^{18} \mathrm{O}_{\text {seawater }}$ that is attributed to changes in the local/regional hydrology was then calculated by subtracting the influence of continental ice volume taken from Waelbroeck et al. (2002).

Table 1

AMS- ${ }^{14} \mathrm{C}$ ages and cal. ages of core MD01-2390

\begin{tabular}{|c|c|c|c|c|c|c|}
\hline Lab. code NUTA2- ${ }^{\mathrm{a}}$ & Depth $(\mathrm{cm})$ & AMS- ${ }^{14} \mathrm{C}$ age $(\mathrm{yr} \mathrm{BP})^{\mathrm{a}}$ & Error $1 \sigma$ & Foraminifera species & Calibrated age (cal-yr BP $)^{\mathrm{b}}$ & $1 \sigma$ range $^{\mathrm{c}}$ \\
\hline 7997 & 12.5 & 1505 & $+35 \pm 35$ & G. sacculifer & 1050 & $1085-1000$ \\
\hline 7998 & 92.5 & 3550 & $+35 \pm 35$ & G. sacculifer & 3430 & $3460-3380$ \\
\hline 7999 & 317.5 & 9860 & $+45 \pm 45$ & G. sacculifer & 10,610 & $11,100-10,340$ \\
\hline- & 352.5 & Analogue & - & - & $11,600^{\mathrm{d}}$ & - \\
\hline- & 442.5 & Analogue & - & - & $14,700^{\mathrm{d}}$ & - \\
\hline 8036 & 557.5 & 14,080 & $+55 \pm 55$ & G. sacculifer + G. ruber & 16,310 & $16,540-16,080$ \\
\hline
\end{tabular}

${ }^{a}$ Measured at the Nagoya University Center for Chronological Research, Japan.

${ }^{\mathrm{b}} \mathrm{AMS}-{ }^{14} \mathrm{C}$ ages have been calibrated using the program CALIB 4.3 (Stuiver et al., 1998).

${ }^{\mathrm{c}} 1 \sigma$ enclosing $68.3 \%$ of probability distribution (Stuiver et al., 1998).

${ }^{\mathrm{d}}$ Analogue oxygen isotope stratigraphic ages of 11,600 cal-yr BP and 14,700 cal-yr BP have been assigned to the end of the YD (Alley et al., 1993; Grootes and Stuiver, 1997) and to the onset of the Bølling Transition (Stuiver et al., 1995; Stuiver and Grootes, 2000). 


\subsection{Carbonate preservation}

Carbonate preservation was evaluated using planktonic foraminiferal fragmentation and pteropod abundances. Fragmentation is expressed as $F \%=(F /(F+W)) \times 100$, where $F$ is the total number of planktonic foraminiferal fragments and $W$ is the total number of whole planktonic foraminifera in the sample (Thunell, 1976).

\section{Results and discussion}

\subsection{Age control and oxygen isotope record}

The age model of core MD01-2390 is based on four AMS- ${ }^{14} \mathrm{C}$ ages and on planktonic foraminiferal oxygen isotope stratigraphy (Table 1). Analogue oxygen isotope stratigraphic ages of 11,600 and 14,700 cal-yr BP have been tentatively assigned to the end of the Younger Dryas (YD; 11,600 cal-yr BP) and the onset of the Bølling Transition (14,700 cal-yr BP), respectively. The assignment of these 'North Atlantic standard ages' to the $\delta^{18} \mathrm{O}$ record of core MD01-2390 is justified by the fact that radiocarbon-dated SST records from the southern SCS reveal a close synchroneity between deglacial SST variability and Greenland temperatures during the Bølling Transition and the YD (Kienast et al., 2001; Steinke et al., 2001). The investigated upper $900 \mathrm{~cm}$ of core MD01-2390 covers a continuous succession from $\sim 22,000$ to $\sim 1000$ cal-yr BP. Sedimentation rates range from $\sim 70 \mathrm{~cm} / \mathrm{ka}$ during the glacial intervals to $30 \mathrm{~cm} / \mathrm{ka}$ during the Holocene. Higher sedimentation rates during glacial times are attributed to increased incision by rivers on the exposed Sunda Shelf during sea-level lowstand resulting in sediment bypassing on the shelf and thus high rates of sediment supply to the continental slope and deep-sea basin (e.g. Schönfeld and Kudrass, 1993; Steinke et al., 2003).

The oxygen isotope record of $G$. ruber s.s. exhibits a twostep transition from glacial to interglacial conditions, with a pronounced step towards lighter values around 14,700 cal-yr BP $(410-450 \mathrm{~cm}$ depth in core $)$ and a second decrease between 11,600 and 10,000 cal-yr BP $(310-300 \mathrm{~cm}$ depth in core; Fig. 3a). Distinctly heavier $\delta^{18} \mathrm{O}$ values occur between 13,000 and 11,600 cal-yr BP $(350-370 \mathrm{~cm}$ depth in core) that are associated with the YD climate rebound. The $\delta^{18} \mathrm{O}_{G \text {. ruber }}$ record of core MD01-2390 is characterized by an average amplitude between LGM (24,000-18,000 cal-yr BP, EPILOG chronozone; Mix et al., 2001) and Late Holocene (3000-1000 cal-yr BP) of $\Delta \delta^{18} \mathrm{O} \sim 1.2 \%$ that is close to the global ice volume effect of $\sim 1.0 \pm 0.1 \%$ o (Schrag et al., 1996; Shackleton, 2000). The LGM-Late Holocene $\Delta \delta^{18} \mathrm{O}_{\text {G. ruber }}$ amplitude is in relatively good agreement with previously published records from the Sulu Sea (Linsley, 1996; Oppo et al., 2003; Rosenthal et al., 2003 ) but is smaller by ca $0.5 \%$ compared to previous published records from the SCS (e.g. core V35-5, Duplessy et al., 1991; core 17964, Wang et al., 1999). This may have been partly due to the assignment of the heaviest values as representative for the LGM. Recent ${ }^{14} \mathrm{C}$-dated highresolution $\delta^{18} \mathrm{O}$ records, however, have revealed that heaviest $\delta^{18} \mathrm{O}$ values occur during the time interval of the North Atlantic Heinrich 1 (e.g. Oppo et al., 2003; Rosenthal et al., 2003; this study).

Assuming no salinity change, this translates into a temperature change of only $\sim 1{ }^{\circ} \mathrm{C}$ when using the $\delta^{18} \mathrm{O}$-temperature relationship of $0.2 \% /{ }^{\circ} \mathrm{C}$ for $G$. ruber in the Indian Ocean (Duplessy et al., 1981). Given the evidence of a LGM cooling of $3.1 \pm 0.6{ }^{\circ} \mathrm{C}$ (see below), however, we suggest that the SCS must have been less saline during the LGM than today. In order to compensate for an average temperature effect on the $\delta^{18} \mathrm{O}_{G \text {.ruber }}$ of $\sim 0.6 \%$, SCS surface waters must have been significantly fresher in order to maintain the LGM-Late Holocene $\Delta \delta^{18} \mathrm{O}$ change of $\sim 1.2 \%$.

\section{2. $\mathrm{Mg} / \mathrm{Ca}-\mathrm{SST}$ variability in the southern SCS over the last 22,000 years}

The $\mathrm{Mg} / \mathrm{Ca}-\mathrm{SST}$ estimates of core MD01-2390 show a LGM to Late Holocene (3000-1000 cal-yr BP) average temperature change of $3.1 \pm 0.6^{\circ} \mathrm{C}\left(\sim 25^{\circ} \mathrm{C}\right.$ vs. $\sim 28^{\circ} \mathrm{C}$; Figs. $3 \mathrm{~b}$ and $4 \mathrm{~b})$. The LGM-Late Holocene temperature contrast is in relatively good agreement with previously published temperature reconstructions based on alkenone and $\mathrm{Mg} / \mathrm{Ca}$ data that suggest a general cooling of $2-3{ }^{\circ} \mathrm{C}$ in the western tropical Pacific marginal seas $\left(\mathrm{SCS}, 2.6-2.8^{\circ} \mathrm{C}\right.$, Pelejero et al., 1999b; $2.5^{\circ} \mathrm{C}$, Huang et al., 2002; Sulu Sea, $2.3 \pm 0.5^{\circ} \mathrm{C}$, Rosenthal et al., 2003) and open western Pacific $\left(2.8 \pm 0.6{ }^{\circ} \mathrm{C}\right.$, Lea et al., 2000; $2{ }^{\circ} \mathrm{C}$, Stott et al., 2002; $3.3 \pm 0.6{ }^{\circ} \mathrm{C}$, Visser et al., 2003). A higher LGM-Late Holocene average temperature difference compared with previous reconstructions from the SCS could be due to the fact that the entire $G$. ruber population instead of 'morphospecific' samples was used for $\mathrm{Mg} / \mathrm{Ca}$ measurements of the glacial period. During the LGM, the abundance of G. ruber is very low due to dilution processes (Fig. 3c) with an increased abundance of $G$. ruber s.l. morphotypes relative to $G$. ruber s.s. Samples for $\mathrm{Mg} / \mathrm{Ca}$ analyses of this time interval that did not contain enough $G$. ruber s.s. morphotypes were therefore supplemented with $G$. ruber s.1. specimens. A recent comparison of $\mathrm{Mg} / \mathrm{Ca}$ measurements of the two $G$. ruber morphotypes ( $G$. ruber s.s. and G. ruber s.1.) from core-top and downcore material showed that $G$. ruber s.s. specimens generally reveal higher $\mathrm{Mg} / \mathrm{Ca}$ ratios compared to G. ruber s.l. (Steinke et al., 2005). These results may suggest that $G$. ruber s.l. specimens precipitated their shells in slightly colder/deeper surface waters than $G$. ruber s.s. specimens. This is corroborated by stable oxygen isotope studies on core-top material from the SCS (Wang, 2000; Löwemark et al., 2005), and from plankton tow and pumping studies from the Pacific by Kuroyanagi and Kawahata (2004). Wang (2000) interpreted these differences in the oxygen stable isotopes of two $G$. ruber morphotypes $(G$. ruber s.s. and $G$. ruber s.l.) to reflect a different depth habitat with $G$. ruber s.s. inhabiting the 


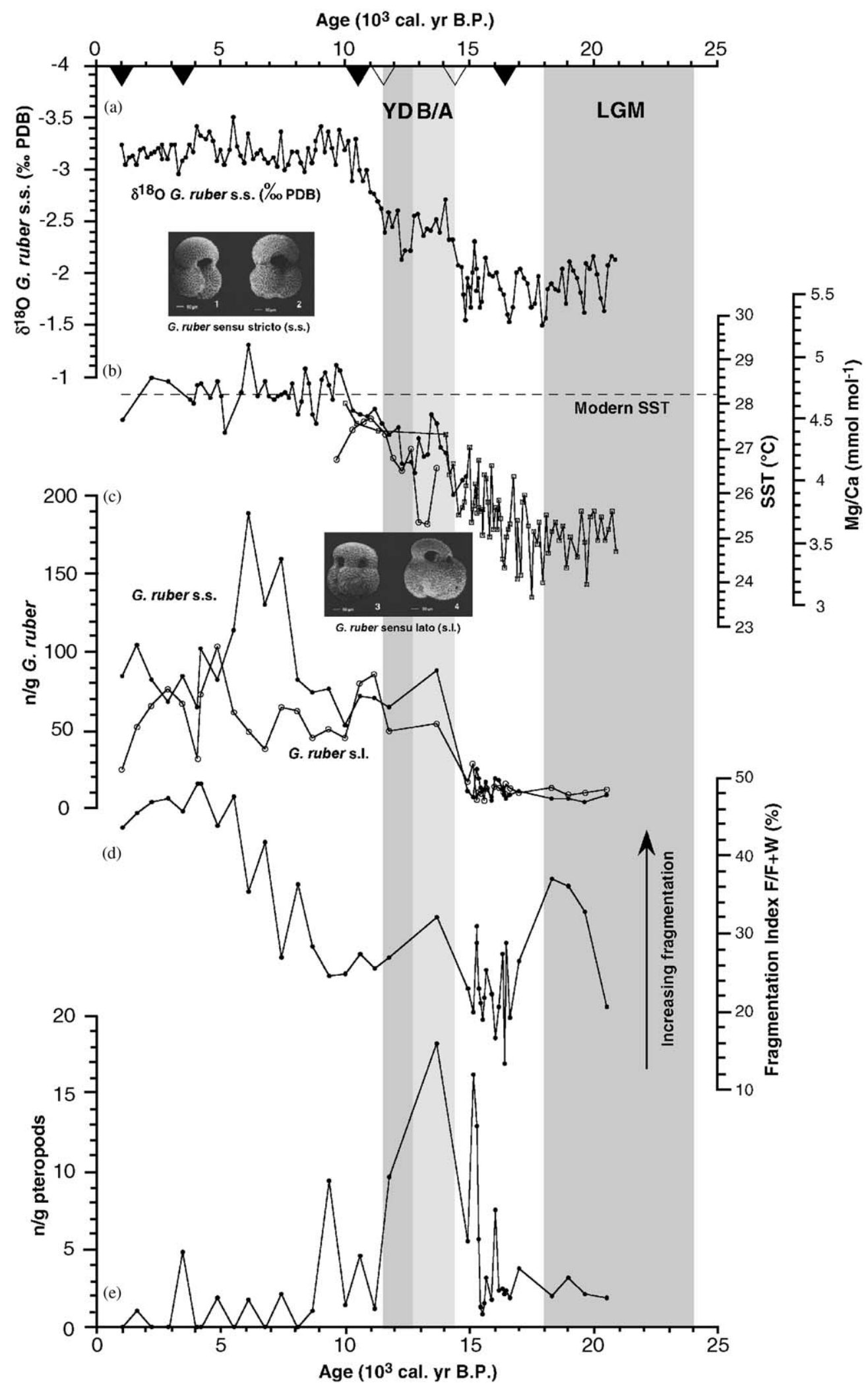

Fig. 3. Tracer records of core MD01-2390 since the LGM. (a) Oxygen isotope data of G. ruber s.s. (b) Mg/Ca record and inferred SSTs: solid and open dots indicate SST estimates based on G. ruber s.s. and G. ruber s.l. morphotypes, respectively; open boxes based on a mixture of $G$. ruber s.s. and $G$. ruber s.l. morphotypes. (c) Absolute abundances of the G. ruber morphotypes, G. ruber s.s. and G. ruber s.l. (d) Fragmentation index and (e) absolute abundance of pteropods. Solid and open triangles indicate age control points based on ${ }^{14} \mathrm{C}$ ages and analogue oxygen isotope stratigraphic ages, respectively. Shaded bars indicate the Younger Dryas (YD; ages adopted from Stuiver et al., 1995), Bølling-Allerød (B/A; ages adopted from Stuiver et al., 1995) and Last Glacial Maximum (LGM; 18,000-24,000 cal-yr BP; EPILOG chronozone; Mix et al., 2001) intervals. 


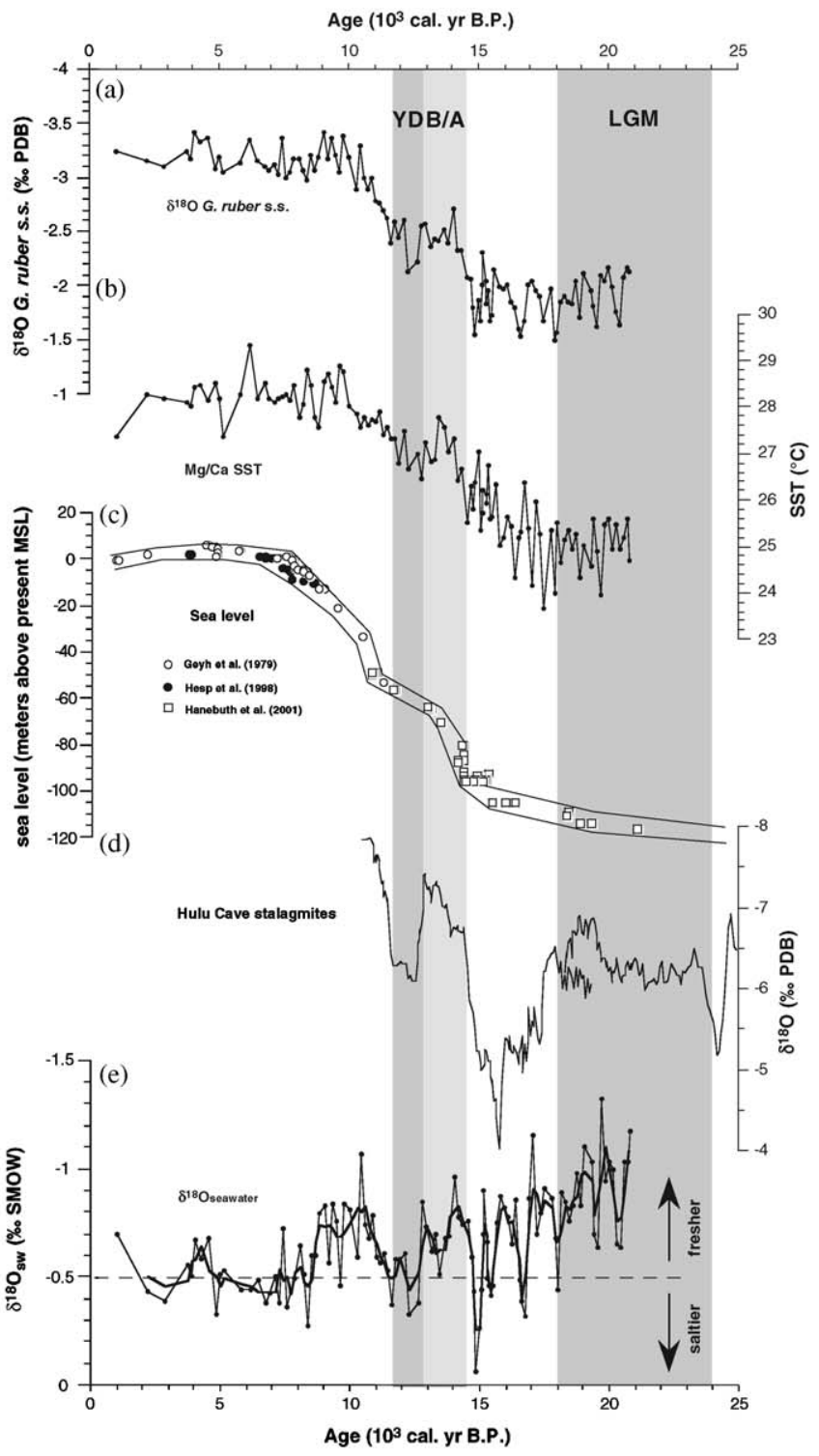

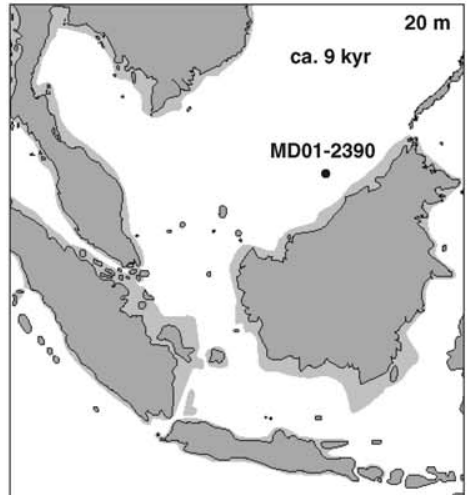

(f)

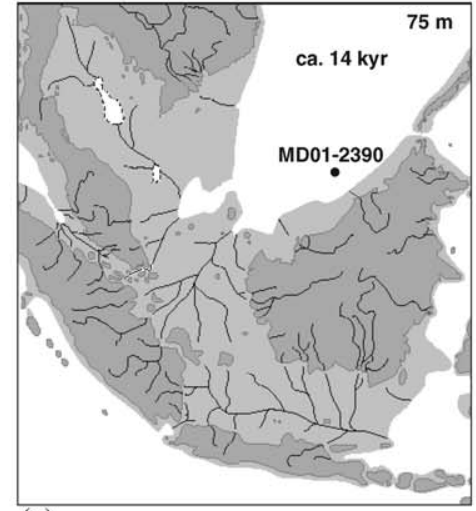

(g)

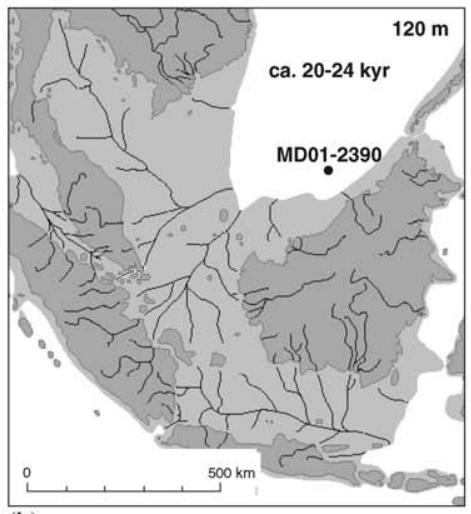

(h)

Fig. 4. Inferred paleo- $\delta^{18} \mathrm{O}_{\text {seawater }}$ record of core MD01-2390. (a) Oxygen isotope data; (b) $\mathrm{Mg} / \mathrm{Ca}-\mathrm{SST}$ estimates; (c) estimated sea-level curve for the Sunda Shelf region compiled from Geyh et al. (1979), Hesp et al. (1998) and Hanebuth et al. (2000); (d) Hulu Cave stalagmite $\delta^{18} \mathrm{O}$ record (Wang et al., 2001); (e) $\delta^{18} \mathrm{O}_{\text {seawater }}$ record; (f) and (g) maps depicting shorelines at 20, 75 and $120 \mathrm{~m}$ below present sea level (Voris, 2000; taken from http://fmnh.org/ research_collections/zoology/2000_sites/seamaps). Shaded bars indicate the Younger Dryas (YD; ages adopted from Stuiver et al., 1995), Bølling-Allerød (B/A; ages adopted from Stuiver et al., 1995) and Last Glacial Maximum (LGM; 18,000-24,000 cal-yr BP; EPILOG chronozone; Mix et al., 2001) intervals. 
upper $30 \mathrm{~m}$ of the water column and G. ruber s.l. inhabiting depths below $30 \mathrm{~m}$. Thus, we suggest that a higher contribution of G. ruber s.l. morphotypes would shift the average glacial temperatures to slightly colder conditions during the LGM. However, a downcore oxygen isotopic study of site 17939 that is located close to the Pearl River mouth (see Fig. 1 for the site location) showed that the isotopic difference between the two morphotypes diminished during the last glaciation, especially during the LGM (Wang, 2000). Stronger winter monsoon winds caused a stronger mixing of the surface water layers, bringing subsurface water to the surface that resulted in a higher production of $G$. ruber s.l. and reduced the isotopic difference between the morphotypes (Wang, 2000). Similarly, assuming a stronger mixing of the upper layer of the water column in the southern SCS during the last glacial, a stronger mixing may have also reduced the $\mathrm{Mg} / \mathrm{Ca}$ temperature difference between the two morphotypes. In that case, the slightly higher cooling during the last glacial as inferred from our temperature record is not attributed to the use of the entire $G$. ruber population instead of 'morpho-specific' samples.

Based on our downcore $\mathrm{Mg} / \mathrm{Ca}-\mathrm{SST}$ estimates of the two G. ruber morphotypes (Fig. 3b), however, increased temperature differences between the two morphotypes occurred during periods of lower salinity, especially during the Bølling/Allerød and the Early Holocene period (Fig. 4e) that may have resulted in the development of a well-stratified upper water column. Similarly, we would also expect a well-stratified upper water column during the LGM due to a higher freshwater contribution at site MD01-2390 when the river mouths shifted closer to the coring site during glacial shelf exposure (see Section 4.3 and discussion therein). A well-stratified upper water column during the LGM may have increased the average $\mathrm{Mg} / \mathrm{Ca}$ temperature difference of the two morphotypes. In that scenario, the slightly stronger cooling during the LGM compared with other SST records from the SCS (see below) may be attributed to a higher contribution of G. ruber s.l. morphotypes relative to G. ruber s.s., and therefore our LGM SST estimates seem to be slightly overestimated.

Recent transfer function techniques from planktonic foraminifera counts of core MD97-2151 from the southern SCS (see Fig. 1 for core locations), however, exhibit a much smaller cooling $\left(\sim 1^{\circ} \mathrm{C}\right.$; Chen et al., 2005) compared with alkenone SSTs of the same core $\left(\sim 2{ }^{\circ} \mathrm{C}\right.$; Huang et al., 2002) in the southern SCS during the LGM relative to modern conditions. Chen et al. (2005) suggest that the discrepancy of $\sim 1{ }^{\circ} \mathrm{C}$ between faunal and alkenone SST estimates of the LGM may be attributed to a differential sensitivity of the methods used, or a different seasonal preference of planktonic foraminifera and coccoliths. Our previous studies of core 18294 located in the southern SCS exhibit the same discrepancies between alkenone and faunal SST estimates (Steinke, 2001; M. Kienast, unpubl. alkenone data). Despite higher abundances of cool to temperate water species at site 18294 during the last glaciation, planktonic transfer function methods show unchanged SSTs, whereas alkenone data yield a distinct glacial cooling of $\sim 2{ }^{\circ} \mathrm{C}$. Pflaumann and Jian (1999) conclude that planktonic foraminiferal SST estimates of the northern SCS are mainly governed by the varying percentages of Pulleniatina obliquiloculata and Neogloboquadrina pachyderma. Therefore, we speculate that the minor $1{ }^{\circ} \mathrm{C}$ cooling during the LGM may be linked to an increased abundance of $P$. obliquiloculata in the glacial southern SCS as presented by Chen et al. (2005). Higher relative abundances of $P$. obliquiloculata in the glacial southern SCS compared with lower abundances in the northern SCS are supported by findings of Jian et al. (1999), Huang et al. (2002), Steinke and Chen (2003) and Xu et al. (2005), implying a local southern SCS phenomenon. Faunal SST estimates of core MD97-2151 display distinct lowered SSTs around 17,000-15,000 cal-yr BP, when relative abundances of $P$. obliquiloculata are low (Huang et al., 2002), corroborating the assertion that faunal SST estimates are mainly driven by fluctuations in the abundance of $P$. obliquiloculata (Pflaumann and Jian, 1999). Despite higher abundances of cool to temperate water species (e.g. N. pachyderma dex.), the minor $1{ }^{\circ} \mathrm{C}$ cooling during the LGM (Chen et al., 2005) may be linked to increased abundance of $P$. obliquiloculata in the glacial southern SCS. SST estimates in the southern SCS based on planktonic foraminiferal transfer functions seem incapable of recording any significant glacial/interglacial SST changes, due to an unexplained high concentration of the warm water species $P$. obliquiloculata, which potentially masks any significant changes in SST at this site.

Deglacial warming started around 18,000 cal-yr BP. A gradual warming of $\sim 1{ }^{\circ} \mathrm{C}$ is followed by an accelerated/ abrupt increase in temperature $\left(\sim 1{ }^{\circ} \mathrm{C}\right)$ at the Bølling Transition around 14,700-14,000 cal-yr BP (Figs. 3b and $4 b)$. The deglacial warming trend is then interrupted by a temperature decrease of $\mathrm{ca} 1{ }^{\circ} \mathrm{C}$ with respect to the preceding Bølling-Allerød that is associated with the YD climate rebound. A third warming step started around $11,600 \mathrm{cal}-\mathrm{yr} \mathrm{BP}$, at the end of the YD. Modern temperatures are reached at 10,000 cal-yr BP. In contrast to recently published $\mathrm{Uk}_{37}$-SSTs records from the SCS (Pelejero et al., 1999b; Steinke et al., 2001; Huang et al., 2002; Kienast et al., 2001; see Kiefer and Kienast, 2005 for a recent review), that suggest a 'Greenland-type' deglacial warming (as defined by Kiefer and Kienast, 2005), deglacial warming based on $\mathrm{Mg} / \mathrm{Ca}$ ratios of core MD01-2390 is characterized by a rather continuous warming with a marked interruption by the YD cooling, but without any obvious response to the Heinrich 1 cooling in the North Atlantic as previously described by Pelejero et al. (1999b) and Huang et al. (2002).

Several studies of $\mathrm{Mg} / \mathrm{Ca}$ in core-top foraminifera suggest that post-depositional, partial dissolution can be an important control on the $\mathrm{Mg} / \mathrm{Ca}$ ratios (e.g. Brown and Elderfield, 1996; Rosenthal et al., 2000). However, several lines of evidence argue against a significant dissolution 
influence on the $\mathrm{Mg} / \mathrm{Ca}$ record over the last 22,000 years and indicate that calcite is well preserved in core MD012390. Core MD01-2390 was recovered well above the modern-day calcite lysocline and the carbonate compensation depth (CCD) that are located approximately at 3000 and $3800 \mathrm{~m}$, respectively (Rottman, 1979; Miao et al., 1994). The present-day aragonite compensation depth (ACD) is located between 1000 and $1200 \mathrm{~m}$ (Miao et al., 1994). Earlier studies reported a deepening of the CCD and ACD by $\sim 400$ and $1200 \mathrm{~m}$, respectively, during the last glacial relative to their present-day positions (Thunell et al., 1992), resulting in an enhanced carbonate preservation in the SCS during the last glaciation (Miao et al., 1994). This is supported by the planktonic foraminiferal fragmentation index yielding values below $50 \%$ over the last 22,000 years that is thought to be a critical value for carbonate dissolution (Fig. 3d). According to the fragmentation index, preservation during glacial times was even better compared to the Holocene (Fig. 3d). Furthermore, pteropods are present throughout the last 22,000 years with slightly increased abundances during the last glaciation (Fig. 3e). This may indicate a better aragonite preservation during the last glaciation which is in relative good agreement with the study of Thunell et al. (1992) who reported a glacial deepening of the ACD relative to the present-day position (see above). Therefore, we believe that variations in foraminiferal $\mathrm{Mg} / \mathrm{Ca}$ over the last 22,000 years are primarily driven by temperature rather than dissolution.

\section{3. $\delta^{18} O_{\text {seawater }}$ variations in the southern $S C S$ over the last 22,000 years}

The $\delta^{18} \mathrm{O}_{\text {seawater }}$ record of core MD01-2390 reveals approximately $0.4 \%$ o lower average $\delta^{18} \mathrm{O}_{\text {seawater }}$ values $(-0.96 \%)$ during the LGM than during the Late Holocene $(-0.54 \%$; Fig. 4e). Assuming that the freshwater end-member determining $\delta^{18} \mathrm{O}$ value in the southern SCS did not change significantly during the LGM, the modern $\delta^{18} \mathrm{O}_{\text {seawater }}$ to surface salinity relationship, $\delta^{18} \mathrm{O}_{\text {seawater }}=0.35(\mathrm{SSS})-11.6$, developed from surface water samples off the southwest coast of Taiwan (Lin et al., 2003), is valid also for the last glacial period. However, most of the sampling sites are located close to the southwest coast of Taiwan, off the Kaoping River system and therefore does not necessarily reflect the surface water conditions of the more 'open ocean' site MD01-2390. The estimated Late Holocene salinities using the Lin et al. (2003) equation (32.4-33.2 psu), however, are very similar to modern-day average SSS at site MD01-2390 ( $\sim 33.5$ psu; Levitus and Boyer, 1994). Moreover, the modern surface water conditions off the southwest Taiwan coast may serve as adequate modern analogue for the glacial conditions of the surface waters in the southern SCS when the core site was located closer to the coast (see Fig. 1). Our glacial

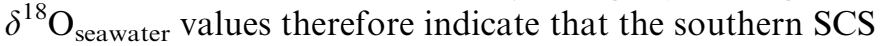
at site MD01-2390 were $\sim 1-1.5$ psu lower during the LGM than modern salinities, suggesting a local decrease in salinity. The assumption of a locally/regionally and temporary constant $(\mathrm{S}): \delta^{18} \mathrm{O}$ relationship (see above), however, is not obvious on glacial-interglacial timescales, and therefore, the SSS estimates should be considered with caution (Rohling and Bigg, 1998; Schmidt, 1999). Furthermore, the amplitude of the estimated glacial salinity changes is uncertain because it strongly depends on the oxygen isotope composition of glacial precipitation that may have changed in the (SE) Asia region during the last glaciation (see Oppo et al., 2003 and references therein). Nevertheless, the sense of SSS changes is likely to be correct.

Another possible source of error in the seawater $\delta^{18} \mathrm{O}$ values is the temperature reconstructions that have been taken into account when correcting the $\delta^{18} \mathrm{O}$ of foraminiferal calcite for temperature-related fractionation of seawater $\delta^{18} \mathrm{O}$ (Epstein et al., 1953). If we consider the faunal estimates to be more reliable (Chen et al., 2005), a glacial cooling of only $1{ }^{\circ} \mathrm{C}$ would consequently lead to unchanged or slightly higher $\delta^{18} \mathrm{O}_{\text {seawater }}$ values compared to modern values. As discussed in Section 4.2, however, our SST estimates based on the $\mathrm{Mg} / \mathrm{Ca}$ seem not to be affected by dissolution processes. However, the contribution of different G. ruber morphotypes used for $\mathrm{Mg} / \mathrm{Ca}$ measurements may have influenced our LGM SST estimates (see Section 4.2). For this reason, more "morpho-specific' data, in particular for the LGM, would be needed to better evaluate the relative influence of the different $G$. ruber morphotypes on the $\mathrm{Mg} / \mathrm{Ca}$ estimates.

Lighter seawater $\delta^{18} \mathrm{O}$ values/lower salinity may reflect increased river run-off from the surrounding southern continents due to enhanced continental wetness, during the last glacial period in the western Pacific (e.g. Oppo et al., 2003 and discussion therein). In addition, sea-level-induced changes in the basin geometry, cutting off the inflow of higher saline waters from the Indo-Pacific when the shallow-sill-depth straits (e.g. Karimata, Sunda and Malacca Straits) were closed during glacial shelf exposure, are interpreted to promote a glacial freshening of these 'marginal' seas (Wang et al., 1999; Pelejero et al, 1999a,b; Oppo et al., 2003; Rosenthal et al., 2003). Terrestrial, marine and modelling studies, however, reveal a controversial picture concerning the mean climatic state (drier vs. humid conditions) of the SE Asian region during the last glacial period (see Section 1). On the basis of this conflicting data, we believe that lower salinity during the LGM at station MD01-2390 was mainly related to a shift of the mouths of Baram, Rajang and North Sunda/ Molengraaff Rivers closer to site MD01-2390 across the emerged shelf during last glacial sea-level lowstand, regardless of any change in the intensity of the East Asian monsoon during the last glaciation (Fig. 4). This is corroborated by sedimentological studies that report highest accumulation rates of fine-grained siliciclastic and terrigenous riverine derived material in front of the glacial exposed Sunda Shelf when the glacial North Sunda/ 
Molengraaff River discharged very close to the investigated sites located on the continental margin of the Sunda Shelf (Steinke et al., 2003). Following the LGM, $\delta^{18} \mathrm{O}_{\text {seawater }}$ steadily increases from $\delta^{18} \mathrm{O}$ values of $\sim-1 \%$ during the LGM to almost modern values of $\sim-0.5 \%$ around 11,000 cal-yr BP (Fig. 4). This is interpreted to reflect the progressive landward displacement of the coastline and the paleo-drainage system on the exposed shelves (Fig. $4 \mathrm{~g}$ and 4h).

The general deglacial increasing trend in salinity is punctuated/superimposed by several short-term shifts towards heavier $\delta^{18} \mathrm{O}_{\text {seawater }}$ around 16,500 and 15,000 cal-yr BP as well as a shift towards lighter values after 15,000 cal-yr BP (Fig. 4e). Within dating uncertainties, we suggest that these two episodes of higher salinity can be attributed to a decrease in summer monsoon precipitation as suggested from the Hulu Cave stalagmite record (Fig. 4d; Wang et al., 2001). Decreasing $\delta^{18} \mathrm{O}_{\text {seawater }}$ values after 15,000 cal-yr BP may indicate the intensification of the summer East Asian monsoon starting around 14,700 cal-yr BP as inferred from the Hulu Cave record (Wang et al., 2001).

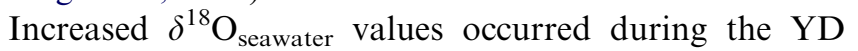
period, possibly reflecting a period of reduced precipitation. However, the interpretation of arid conditions is inconsistent with the observations of An et al. (1993), who postulate a strengthened summer monsoon and increased pedogenesis at the Baxie loess area due to a higher moisture transport during the YD, while simultaneously the winter monsoon remained strong. Unstable climate conditions with rapid fluctuations between dry and wet periods during the YD are also inferred from the Chinese Midivan swamppeat deposits (Zhou et al., 1999), whereas drier conditions are inferred from the Hulu Cave stalagmite record (Wang et al., 2001).

Lower $\delta^{18} \mathrm{O}_{\text {seawater }}$ values compared to Late Holocene values occur between 11,000 and 8,000 cal-yr BP. Lower $\delta^{18} \mathrm{O}_{\text {seawater }}$ values during this period appear to be linked to the Preboreal-Early Holocene Maximum in summer monsoon precipitation and river run-off as previously described by studies of the East Asian (Wang et al., 1999) and Indian monsoons (e.g. Sirocko et al., 1993; Overpeck et al., 1996). Paleo-ecological investigations in the NE Cambodia also indicate that summer monsoon intensity increased during the Early Holocene (Maxwell, 2001). Almost modern hydrographic conditions were established around 7,000 cal-yr BP, when sea level roughly reached the modern coastline and the southern Straits were completely opened, allowing the inflow of warm and saline water from the Indo-Pacific.

\section{Conclusions}

Changes in the local freshwater budget over the last 22,000 years have been reconstructed for one sediment core from the tropical southern SCS. Based on the combined study of $\mathrm{Mg} / \mathrm{Ca}$ and oxygen isotopes on the planktonic foraminfera G. ruber s.s., several conclusions can be drawn:

(1) Lower salinity at site MD01-2390 during the LGM primarily reflects the shift of the Baram, Rajang and Molengraaff/North Sunda Rivers closer to site MD01-2390 across the emerged shelf during glacial shelf exposure. However, an influence by the closure of the southern straits, cutting off the inflow of higher saline waters from the Indo-Pacific into the SCS Basin, cannot be excluded. Due to the potential overriding control on the local freshwater budget by the major drainage systems that moved close to site MD01-2390 with low sea level, no definite conclusions can be drawn from our proxy record concerning the mean tropical climate state (drier vs. wetter) of the southeastern Asian region during the LGM.

(2) The deglacial $\delta^{18} \mathrm{O}_{\text {seawater }}$ changes are mainly controlled by the interrelationship of sea-level-induced environmental changes on the shelf (e.g. phases of retreat and breakdown of the shelf drainage systems) and East Asian monsoon climate change. The deglacial increase in salinity probably indicates a decreasing freshwater influence on site MD01-2390 through the paleo-Baram, the paleo-North Sunda/Molengraaff, the paleo-Rajang river drainage systems due to the progressive landward displacement of the coastline during deglacial flooding. Short-term shifts towards higher and lower salinity are superimposed on the deglacial increasing trend in salinity, possibly indicating periods of abrupt shifts of decreased and increased summer monsoon intensity.

(3) Lower salinity during the Early Holocene $(11,000-8000$ cal-yr BP) may be attributed to an increase in summer monsoonal precipitation, corroborated by previous marine and terrestrial studies that reported a Preboreal-Early Holocene monsoon maximum in precipitation and river run-off in the Asian monsoon region.

\section{Acknowledgements}

We thank the IMAGES Program for allowing access to core MD01-2390. We cordially thank K.-Y. Wei for providing the opportunity to work in his laboratory at the Department of Geosciences, NTU, Taiwan, and the staff at the NCOR core lab repository at NTOU (Keelung, Taiwan) for their assistance during core sampling. We express our gratitude to M. Murayama, Kochi University, and T. Nakamura, Nagoya University, and their teams for AMS- ${ }^{14} \mathrm{C}$ dating. StSt acknowledges a fellowship through the National Science Council (Taiwan) and the Alexandervon-Humboldt-Foundation. This study has been funded by the National Science Council (NSC), Taiwan, through grants to MTC (NSC91-2611-M-019-012-IM, NSC912811-M-019-002) and CCS (NSC93-2116-M-002-036, NSC94-2752-M-002-011-PAE). This study was completed with support from the "Deutsche Forschungsgemeinschaft" through the Research Center Ocean Margins (RCOM), University of Bremen (RCOM contribution 0356). The data in this study is archived and can be 
retrieved at PANGAEA (Publishing Network for Geoscientific and Environmental Data; http://www.pangaea.de, doi:10.1594/pangaea.329730).

\section{References}

Alley, R.B., Meese, D.A., Shuman, C.A., Gow, A.J., Taylor, K.C., Grootes, P.M., White, J.W.C., Ram, M., Waddington, E.D., Mayewski, P.A., Zielinski, G.A., 1993. Abrupt increase in Greenland snow accumulation at the end of the Younger Dryas event. Nature $362,527-529$.

An, Z., 2000. The history and variability of the East Asian paleomonsoon climate. Quaternary Science Reviews 19, 171-187.

An, Z., Kukla, G., Porter, S.C., Xiao, J., 1991. Magnetic susceptibility evidence of monsoon variation on the loess plateau of central China during the last 130,000 years. Quaternary Research 36, 29-36.

An, Z., Porter, S.C., Zhou, W., Lu, Y., Donahue, D.J., Head, M.J., Wu, X., Ren, J., Zheng, H., 1993. Episode of strengthened summer monsoon climate of Younger Dryas age on the Loess Plateau of Central China. Quaternary Research 39, 45-54.

Anand, P., Elderfield, H., Conte, M.H., 2003. Calibration of $\mathrm{Mg} / \mathrm{Ca}$ thermometry in planktonic foraminifera from a sediment trap time series. Paleoceanography 18.

Barker, S., Greaves, M., Elderfield, H., 2003. A study of cleaning procedures used for foraminiferal $\mathrm{Mg} / \mathrm{Ca}$ paleothermometry. Geochemistry Geophysics Geosystems 4, doi:10.1029/2003GC000559.

Barker, S., Cacho, I., Benway, H., Tachikawa, K., 2005. Planktonic foraminiferal $\mathrm{Mg} / \mathrm{Ca}$ as a proxy for past oceanic temperatures: a methological overview and data compilation for the Last Glacial Maximum. Quaternary Science Reviews 24, 821-834.

Bemis, B.E., Spero, H.J., Bijma, J., Lea, D.W., 1998. Reevaluation of the oxygen isotopic composition of planktonic foraminifera: experimental results and revised paleotemperature equations. Paleoceanography 13, $150-160$.

Berger, W.H., Diester-Haas, L., Killingley, J.S., 1978. Upwelling off Northwest Africa; the Holocene decrease as seen in carbon isotopes and sedimentological indicators. Oceanologica Acta 1, 3-7.

Brown, S.J., Elderfield, H., 1996. Variations in $\mathrm{Mg} / \mathrm{Ca}$ and $\mathrm{Sr} / \mathrm{Ca}$ ratios of planktonic foraminifera caused by postdepositional dissolution: evidence of shallow Mg-dependent dissolution. Paleoceanography 11, 543-551.

Bush, A.B.G., 2004. Modelling of Late Quaternary climate over Asia: a synthesis. Boreas 33, 155-163.

Bush, A.B.G., Fairbanks, R.G., 2003. Exposing the Sunda Shelf: tropical response to eustatic sea level change. Journal of Geophysical Research 108, doi:10.1029/2002JD003027.

Chen, M.-T., Huang, C.-C., Pflaumann, U., Waelbroeck, C., Kucera, M., 2005. Estimating glacial western Pacific sea-surface temperature: methodological overview and data compilation of surface sediment planktic foraminifer faunas. Quaternary Science Reviews 24, 1049-1062.

Dam, R.A.C., Fliun, J., Supran, P., Van der Kaars, S., 2001. Palaeoenvironmental developments in the Lake Tondano area (N. Sulawesi, Indonesia) since 33,000 yr B.P. Paleogeography, Palaeoclimatology, Palaeoecology 171, 147-183.

Dekens, P.S., Lea, D.W., Pak, D.K., Spero, H.J., 2002. Core top calibration of $\mathrm{Mg} / \mathrm{Ca}$ in tropical foraminifera: refining paleotemperature estimation. Geochemistry Geophysics Geosystems 3, doi:10.1029/ $2001 \mathrm{GC} 000200$.

Ding, Y., 1994. Monsoons over China. Kluwer Academics, Norwell, MA $419 \mathrm{pp}$.

Duplessy, J.C., Be, A.W.H., Blanc, P.L., 1981. Oxygen and carbon isotope composition and biogeographic distribution of planktonic foraminfera in the Indian Ocean. Paleogeography Palaeoclimatology Palaeoecology 33, 9-46.

Duplessy, J.C., Bard, E., Arnold, M., Shackleton, N., Duprat, J., Labeyrie, L., 1991. How fast did the ocean-atmosphere system run during the last deglaciation? Earth and Planetary Science Letters 103, $27-40$.

Elderfield, H., Ganssen, G., 2000. Past temperature and $\delta^{18} \mathrm{O}$ of surface ocean waters inferred from foraminiferal $\mathrm{Mg} / \mathrm{Ca}$ ratios. Nature 405 , 442-445.

Epstein, S., Buchsbaum, H.A., Lowenstam, H.A., Urey, H.C., 1953. Revised carbonate-water isotopic temperature scale. Bulletin of the Geological Society of America 64, 1315-1326.

Flenley, J.R., 1998. Tropical forests under the climates of the last 30,000 years. Climate Change 39, 177-197.

Geyh, M.A., Kudrass, H.-R., Streif, H., 1979. Sea-level changes during the late Pleistocene and Holocene in the Strait of Malacca. Nature 278, 441-443.

Grootes, P.M., Stuiver, M., 1997. Oxygen 18/16 variability in Greenland snow and ice with $10^{-3}$ to $10^{5}$-year time resolution. Journal of Geophysical Research 102, 26,455-26,470.

Hanebuth, T., Stattegger, K., Grootes, P.M., 2000. Rapid flooding of the Sunda Shelf: a late-glacial sea-level record. Science 288, 1033-1035.

Hastings, D.W., Kienast, M., Steinke, S., Whitko, A.A., 2001. A comparison of three independent paleotemperature estimates from a high resolution record of deglacial SST records in the tropical South China Sea. EOS 82 PP12B-10.

Hellermann, S., Rosenstein, M., 1983. Normal monthly wind stress over the world ocean with error estimates. Journal of Physical Oceanography 13, 1093-1104.

Hesp, P.A., Hung, C.C., Hilton, M., Ming, C.L., Turner, I.M., 1998. A first tentative Holocene sea-level curve for Singapore. Journal of Coastal Research 14, 308-314.

Hiscott, R.N., 2001. Depositional sequences controlled by high rates of sediment supply, sea-level variations, and growth faulting: the Quaternary Baram Delta of northwestern Borneo. Marine Geology $175,67-102$.

Holbourn, A., Kiefer, T., Pflaumann, U., Rothe, S. (Eds.), 2002. Les rapport des campagnes a la mer. WEPAMA Cruise MD 122/IMAGES VII. Institut Polaire Francais-Paul-Emile Victor (IPEV), Plouzane, France (Ref. OCE/2002/01), 453pp.

Hope, G., 2001. Environmental change in the Late Pleistocene and later Holocene at Wanda site, Soroako, South Sulawesi, Indonesia. Paleogeography, Palaeoclimatology, Palaeoecology 171, 129-145.

Hu, J., Peng, P., Fang, D., Jia, G., Jian, Z., Wang, P., 2003. No aridity in Sunda Land during the last glaciation: evidence from molecularisotopic stratigraphy of long-chain n-alkanes. Paleogeography, Palaeoclimatology, Palaeoecology 201, 269-281.

Huang, C., Huang, C., Chen, M., 2003. Centennial to millennial scale hydrographic variations in the northern and southern South China Sea during the past 10-70 kyr. Geophysical Research Abstracts 5, 05663.

Huang, C.-C., Chen, M.-T., Lee, M.-Y., Wei, K.-Y., Huang, C.-Y., 2002. Planktic foraminifer faunal sea surface temperature records of the past two glacial terminations in the South China Sea near Wan-An shallow (IMAGES core MD97-2151). Western Pacific Earth Sciences 2, 1-14.

Huang, C.-Y., Liew, P.-M., Zhao, M., Chang, T.-C., Kuo, C.-M., Chen, M.-T., Wang, C.-H., Zheng, L.-F., 1997a. Deep sea and lake records of the Southeast Asian paleomonsoons for the last 25 thousand years. Earth and Planetary Science Letters 146, 59-72.

Huang, C.-Y., Wu, S.-F., Zhao, M., Chen, M.-T., Wang, C.-H., Tu, X., Yuan, P.B., 1997b. Surface ocean and monsoon climate variability in the South China Sea since the last glaciation. Marine Micropaleontology 32, 71-94.

Jian, Z., Wang, L., Kienast, M., Sarnthein, M., Kuhnt, W., Lin, H., Wang, P., 1999. Benthic foraminiferal paleoceanography of the South China Sea over the last 40,000 years. Marine Geology 156, 159-186.

Kaplan, J.O., 2002. Wetlands at the Last Glacial Maximum: distribution and methane emissions. Geophysical Research Letters 29, doi:10.1029/ 2001 GL013366.

Kiefer, T., Kienast, M., 2005. Patterns of deglacial warming in the Pacific Ocean: a review with emphasis on the time interval of Heinrich event 1. Quaternary Science Reviews 24, 1063-1081. 
Kienast, M., Steinke, S., Stattegger, K., Calvert, S.E., 2001. Synchronous tropical South China Sea SST change and Greenland warming during deglaciation. Science 291, 2132-2134.

Kuhnt, W., Holbourn, A., Hall, R., Zuvela, M., Käse, R., 2004. Neogene history of the Indonesian throughflow. In: Clift, P., Wang, P., Kuhnt, W., Hayes, D. (Eds.), Continent-Ocean Interactions within East Asian Marginal Seas. Geophysical Monograph 149. American Geophysical Union, Washington, DC, pp. 299-320.

Kuroyanagi, A., Kawahata, H., 2004. Vertical distribution of living planktonic foraminifera in the seas around Japan. Marine Micropaleontonlogy 53, 173-196.

Lea, D.W., Pak, D.K., Spero, H.J., 2000. Climate impact of late Quaternary equatorial Pacific sea surface temperature variations. Science 289, 1719-1724.

Levitus, S., Boyer, T., 1994. World Ocean Atlas Volume 4: Temperature. NOAA Atlas NESDIS, US Government. Printing Office.

Lin, I.-T., Wang, C.-H., Lin, S., 2003. Seasonal variations of oxygen isotopic compositions in the Pingtung coastal waters of Taiwan. Western Pacific Earth Sciences 3, 21-32.

Linsley, B.K., 1996. Oxygen-isotope record of sea level and climate variations in the Sulu Sea over the past 150,000 years. Nature 380, 234-237.

Löwemark, L., Hong, W.-L., Yui, T.-F., Hung, G.-W., 2005. A test of different factors influencing the isotopic signal of planktonic foraminifers in surface sediments from the northern South China Sea. Marine Micropaleontology 55, 49-62.

Mangini, A., Schlosser, P., 1986. The formation of eastern mediterranean sapropels. Marine Geology 72, 115-124.

Matisoff, G., 1982. Mathematical models of bioturbation. In: McCall, P.L., Tevesz, M.J.S. (Eds.), Animal-Sediment Relations Topics in Geobiology, vol. 2. Plenum Press, New York, pp. 289-330.

Maxwell, A.L., 2001. Holocene monsoon changes inferred from lake sediment pollen and carbonate records, northeastern Cambodia. Quaternary Research 56, 390-400.

Miao, Q., Thunell, R.C., Anderson, D.M., 1994. Glacial-Holocene carbonate dissolution and sea surface temperatures in the South China and Sulu Seas. Paleoceanography 9, 269-290.

Mix, A.C., Bard, E., Schneider, R., 2001. Environmental processes of the ice age: land, oceans, glaciers (EPILOG). Quaternary Science Reviews 20, 627-657.

Molengraaff, G.A.F., 1921. Modern deep-sea research in the East Indian Archipelago. Geographical Journal 57, 95-121.

Oppo, D.W., Linsley, B.K., Rosenthal, Y., Dannenmann, S., Beaufort, L., 2003. Orbital and suborbital climate variability in the Sulu Sea, western tropical Pacific. Geochemistry Geophysics Geosystems 4 , doi:10.1029/2001GC000260.

Overpeck, J., Anderson, D., Trumdore, S., Prell, W., 1996. The southwest Indian monsoon over the last 18000 years. Climate Dynamics 12, 213-225.

Paillard, D., Labeyrie, L., Yiou, P., 1996. Macintosh program performs time series analysis. EOS 77, 379.

Pelejero, C., Kienast, M., Wang, L., Grimalt, J.O., 1999a. The flooding of Sundaland during the last deglaciation: imprints in hemipelagic sediments from the southern South China Sea. Earth and Planetary Science Letters 171, 661-671.

Pelejero, C., Grimalt, J.O., Heilig, S., Kienast, M., Wang, L., 1999b. Highresolution $\mathrm{U}_{37}^{\mathrm{k}}$ temperature reconstructions in the South China Sea over the past 220 kyr. Paleoceanography 14, 224-231.

Penny, D., 2001. A 40,000 year palynological record from north-east Thailand: implications for biogeography and palaeo-environmental reconstructions. Palaeogeography, Palaeoclimatology, Palaeoecology $171,97-128$.

Pflaumann, U., Jian, Z., 1999. Modern distribution patterns of planktonic foraminifera in the South China Sea and western Pacific: a new transfer technique to estimate regional sea-surface temperatures. Marine Geology 156, 41-83.

Prell, W.L., Kutzbach, J.E., 1987. Monsoon variability over the past 150,000 years. Journal of Geophysical Research 92, 8411-8425.
Rohling, E.J., Bigg, G.R., 1998. Paleosalinity and $\delta^{18}$ O: a critical assessment. Journal of Geophysical Research 1003, 1307-1318.

Rosenthal, Y., Lohmann, G.P., Lohmann, K.C., Sherrell, R.M., 2000. Incorporation and preservation of $\mathrm{Mg}$ in G. sacculifer: implications for reconstructing sea surface temperatures and the oxygen isotopic composition of seawater. Paleoceanography 15, 135-145.

Rosenthal, Y., Oppo, D.W., Linsley, B.K., 2003. The amplitude and phasing of climate change during the last deglaciation in the Sulu Sea, western equatorial Pacific. Geophysical Research Letters 30, 1.

Rosteck, F., Ruhland, G., Bassinot, F.C., Müller, P.J., Labeyrie, L.D., Lancelot, Y., Bard, E., 1993. Reconstructing sea surface temperature and salinity using $\delta^{18} \mathrm{O}$ and alkenone records. Nature 364, 319-321.

Rottman, M.L., 1979. Dissolution of planktonic foraminifera and pteropods in South China Sea sediments. Journal of Foraminiferal Research 9, 41-49.

Schmidt, G.A., 1999. Error analysis of paleosalinity calculations. Paleoceanography 14, 422-429.

Schönfeld, J., Kudrass, H.-R., 1993. Hemipelagic sediment accumulation rates in the South China Sea related to Late Quaternary sea-level changes. Quaternary Research 40, 368-379.

Schrag, D.P., Hampt, G., Murray, D.W., 1996. Pore fluid constraints on the temperature and oxygen isotopic composition of the glacial ocean. Science 272, 1930-1932.

Shackleton, N.J., 2000. The 100,000-year ice-age cycle identified and found to lag temperature, carbon dioxide, and orbital eccentricity. Science 289, 1897-1902.

Shaw, P.-T., Chao, S.-Y., 1994. Surface circulation in the South China Sea. Deep-Sea Research 41, 1663-1683.

Shen, C.-C., Chiu, H.-I., Chu, M.-F., Chen, M.-T., Wei, K.-Y., Steinke, S., 2004. High precision measurement of $\mathrm{Mg} / \mathrm{Ca}$ and $\mathrm{Sr} / \mathrm{Ca}$ ratios in carbonates by cool plasma quadrupole inductively coupled plasma mass spectrometry. EOS 86 PP23B-1440.

Sirocko, F., Sarnthein, M., Erlenkeuser, H., Lange, H., Arnold, M., Duplessy, J.C., 1993. Century-scale events in monsoonal climate over the past 24,000 years. Nature $364,322-324$.

Steinke, S., 2001. Sedimentological and climatic changes during the last deglaciation recorded in cores from the Sunda Shelf margin and continental slope (Southern South China Sea). Ph.D. Thesis, University of Kiel.

Steinke, S., Chen, M.-T., 2003. The spatial distribution patterns of Pulleniatina obliquiloculata in the South China Sea: implications of latitudinal differences in strength of the East Asian winter monsoon intensity during the last deglaciation? Geophysical Research Abstracts 5 EAE03-A-09811.

Steinke, S., Kienast, M., Pflaumann, U., Weinelt, M., Stattegger, K., 2001. A high-resolution sea-surface temperature record from the tropical South China Sea (16,500-3000yr B.P.). Quaternary Research 55, 352-362.

Steinke, S., Kienast, M., Hanebuth, T., 2003. On the significance of sealevel variations and shelf paleo-morphology in governing sedimentation in the southern South China Sea during the last deglaciation. Marine Geology 201, 179-206.

Steinke, S., Chiu, H.-Y, Yu, P.-S., Shen, C.-C., Löwemark, L., Mii, H.-S. Chen, M.-T., 2005. $\mathrm{Mg} / \mathrm{Ca}$ ratios of two Globigerinoides ruber (white) morphotypes: implications for reconstructing past tropical/subtropical surface water conditions. Geochemistry, Geophysics, Geosystems, doi:10.1029/2005GC000926.

Stott, L., Poulsen, C., Lund, S., Thunell, R., 2002. Super ENSO and global climate oscillations at millennial time scales. Science 297, 222-226.

Stuiver, M., Grootes, P.M., 2000. GISP2 oxygen isotope ratios. Quaternary Research 53, 277-284.

Stuiver, M., Grootes, P.M., Braziunas, T.F., 1995. The GISP2 $\delta^{18} \mathrm{O}$ climate record of the past 16,500 years and the role of the sun, ocean, and volcanoes. Quaternary Research 44, 341-354.

Stuiver, M., Reimer, P.J., Bard, E., Beck, J.W., Burr, G.S., Hughen, K.A., Kromer, B., McCormac, G., Van der Pflicht, J., Spurk, M., 1998. 
INTCAL98 Radiocarbon age calibration, 24,000-0 cal BP. Radiocarbon 40, 1041-1083.

Sun, X., Li, X., Luo, Y., Chen, X., 2000. The vegetation and climate at the last glaciation on the emerged continental shelf of the South China Sea. Palaeogeography, Palaeoclimatology, Palaeoecology 160, 301-316.

Taylor, D., Yen, O.H., Sanderson, P.G., Dodson, J., 2001. Late Quaternary peat formation and vegetation dynamics in a lowland tropical swamp, Nee Soon, Singapore. Palaeogeography, Palaeoclimatology, Palaeoecology 171, 269-287.

Thunell, R.C., 1976. Optimum indices of calcium carbonate dissolution in deep-sea sediments. Geology 4, 525-527.

Thunell, R.C., Miao, Q., Calvert, S.E., Pedersen, T.F., 1992. GlacialHolocene biogenic sedimentation patterns in the South China Sea: productivity variations and atmospheric $\mathrm{CO}_{2}$. Paleoceanography 7 , $143-162$.

Trauth, M.H., 1998. Turbo: a dynamic-probabalistic simulation to study the effects of bioturbation on paleoceanographic time series. Computers and Geosciences 24, 433-441.

Van Campo, E., Guiot, J., Peng, C., 1993. A data-based reappraisal of the terrestrial carbon budget at the last glacial maximum. Global Planetary Change 8, 189-201.

Van der Kaars, S., Wang, X., Kershaw, P., Guichard, F., Setiabudi, D.A., 2000. A late Quaternary palaeoecological record from the Banda Sea, Indonesia: patterns of vegetation, climate and biomass burning in Indonesia and northern Australia. Palaeogeography, Palaeoclimatology, Palaeoecology 155, 135-153.

Van der Kaars, S., Penny, D., Tibby, J., Fluin, J., Dam, R.A.C., Suparan, P., 2001. Late Quaternary palaeoecology, palynology and palaeoclimatology of a tropical lowland swamp, Rawa Danau, West-Java Indonesia. Palaeogeography, Palaeoclimatology, Palaeoecology 171, 185-212.

Visser, K., Thunell, R.C., Stott, L.D., 2003. Magnitude and timing of temperature change in the Indo-Pacific warm pool during deglaciation. Nature 421, 152-155.

Visser, K., Thunell, R., Goni, M.A., 2004. Glacial-interglacial organic carbon record from the Makassar Strait, Indonesia: implications for regional changes in continental vegetation. Quaternary Science Reviews 23, 17-27.
Voris, H.K., 2000. Maps of Pleistocene sea levels in South East Asia: shorelines, river systems, time durations. Journal of Biogeography 27, 1153-1167.

Waelbroeck, C., Labeyrie, L., Michel, E., Duplessy, J.C., McManus, J.F., Lambeck, K., Balbon, E., Labracherie, M., 2002. Sea-level and deep water temperature changes derived from benthic foraminifera isotopic record. Quaternary Science Reviews 21, 295-305.

Wang, L., 2000. Isotopic signals in two morphotypes of Globigerinoides ruber (white) from the South Chian Sea: implications for monsoon climate change during the last glacial cycle. Palaeogeography, Palaeoclimatology, Palaeoecology 161, 381-394.

Wang, L., Wang, P., 1990. Late Quaternary paleoceanography of the South China Sea: glacial-interglacial contrasts in an enclosed basin. Paleoceanography 5, 77-90.

Wang, L., Sarnthein, M., Erlenkeuser, H., Grimalt, J., Grootes, P., Heilig, S., Ivanova, E., Kienast, M., Pelejero, C., Pflaumann, U., 1999. East Asian monsoon climate during the Late Pleistocene: high-resolution sediment records from the South China Sea. Marine Geology 156, 245-284.

Wang, P., 1999. Response of Western Pacific marginal seas to glacial cycles: paleoceanographic and sedimentological features. Marine Geology 156, 5-39.

Wang, P., Wang, L., Bian, Y., Jian, Z., 1995. Late Quaternary paleoceanography of the South China Sea: surface circulation and carbonate cycles. Marine Geology 127, 145-165.

Wang, Y.J., Cheng, H., Edwards, R.L., An, Z.S., Wu, J.Y., Shen, C.-C., Dorale, J.A., 2001. A high-resolution absolute-dated late Pleistocene monsoon record from Hulu Cave, China. Science 294, 2345-2348.

Wyrtki, K., 1961. Physical oceanography of the southeast asian waters. NAGA Report, University of California Scripps Institution of Oceanography, La Jolla, CA, Neyenesch Printers, San Diego, CA.

Xu, J., Wang, P., Huang, B., Li, Q., Jian, Z., 2005. Response of planktonic foraminifera to glacial cycles. Mid-Pleistocene change in the southern South China Sea. Marine Micropaleontology 54, 89-105.

Zhou, W., Head, M.J., Lu, X., An, Z., Jull, A.J.T., Donahue, D., 1999. Teleconnection of climatic events between east Asia and polar, high latitude areas during last deglaciation. Palaeogeography, Palaeoclimatology, Palaeoecology 152, 163-172. 